Çukurova Üniversitesi Mühendislik Mimarlık Fakültesi Dergisi, 30(1), 133-140 ss., Haziran 2015

Çukurova University Journal of the Faculty of Engineering and Architecture, 30(1), pp. 133-140, June 2015

\title{
Efficiency Analysis of an Installed Wind Farm
}

\author{
Akın İLHAN ${ }^{1}$, Mehmet BİLGILİ ${ }^{1}$, Beşir ŞAHİN*1 \\ ${ }^{1}$ Çukurova Üniversitesi, Mühendislik Mimarlık Fakültesi, Makine Mühendisliği Bölümü, Adana
}

Geliş tarihi: 12.03 .2015

Kabul tarihi: 25.06 .2015

\begin{abstract}
In this study, efficiency study of five wind turbines of a wind farm were performed using data of wind speed, wind direction, air temperature and electric generation of five turbines selected. Parameters effecting turbine efficiency were also examined.

Analysis of monthly and yearly dominant wind directions for selected turbines was performed. Performed analysis of turbines was also conducted considering the measured wind speed and direction. Aerodynamic characteristics of wind turbines were defined according to the variation of measured wind speeds. Annual energy production of turbines were calculated in order to obtain the most productive and efficient months.
\end{abstract}

Keywords: Efficiency, Electric generation, Wind turbine

\section{Kurulu Bir Rüzgâr Çiftliğinin Verim Analizi}

\section{Özet}

Bu çalışmada bir rüzgâr çiftliğine ait beş adet türbine ait rüzgâr hızı, rüzgâr yönü, güç üretimi ve hava sıcaklığı verileri kullanılarak ilgili türbinlerin verimlilik çalışması yapılmıştır. Türbin verimini etkileyen parametreler de ayrıca incelenmiş̧ir.

Seçilen türbinler için aylık ve yıllık hâkim rüzgâr yönlerinin analizi yapılmıştır. Gerçek hızları ve yönleri dikkate alınarak türbinlerin performans analizi yapılmıştır. Rüzgâr hız değişimlerine göre, türbine aerodinamik karakteristik değerleri çıkarılmıştır. Türbinlerin yıllık enerji üretim değerleri hesaplanarak enerji üretiminin en fazla ve en verimli olduğu aylar belirlenmiştir.

Anahtar Kelimeler: Elektrik üretimi, Rüzgâr türbini, Verim

\footnotetext{
"Yazışmaların yapılacağı yazar: Beşir ŞAHİN, Mühendislik Mimarlık Fakültesi, Makine Mühendisliği Bölümü, Adana.bsahin@cu.edu.tr
} 


\section{INTRODUCTION}

Energy usage is important in enhancing the quality of life besides providing physical comfort and surviving of life. Most of the energy used by humans was obtained from the sun until the discovery of nuclear energy. The sun energy is absorbed and stored up by plants with the specific activity named photosynthesis in order to provide energy found in foodstuff. Fossil fuels which are also derived from the sun were also produced of rotten plants lived million years ago. Energy generated by the sun develops wind formation in the atmosphere. This operates wind rotors for years. Nowadays, the world demand of energy grows rapidly and this demand will continue to grow substantially in coming years because of high growth of populations, social, economic and industrial developments. High rate of energy demand, rapid increase of oil price and negative impact of fossil fuels on the environment gave tremendous attention to wind energy all over the world. In order to convert wind energy into electricity one needs to use a wind turbine. Wind is an indirect product of the sun energy. There are lots of variations in wind speed from stagnant velocities to hurricanes.

The aim of the work is to study the performance of installed turbines in order to see the power produced on the feasibility basis.

Increase of the petrol cost and limitations in traditional energy sources enhanced interest to wind energy again. By the encouragements and formal research studies, lots of new turbine designs were accomplished. The equation demonstrating the relation between wind speed and generated power are given in equation 1. Change of wind potential with respect to the wind speed is depicted in Figure 1.

$P_{W}=\frac{1}{2} \rho A V^{3}$

\section{PREVIOUS STUDIES}

Bilgili et al. (2004) researched wind energy potential in eastern regions of Turkey such as

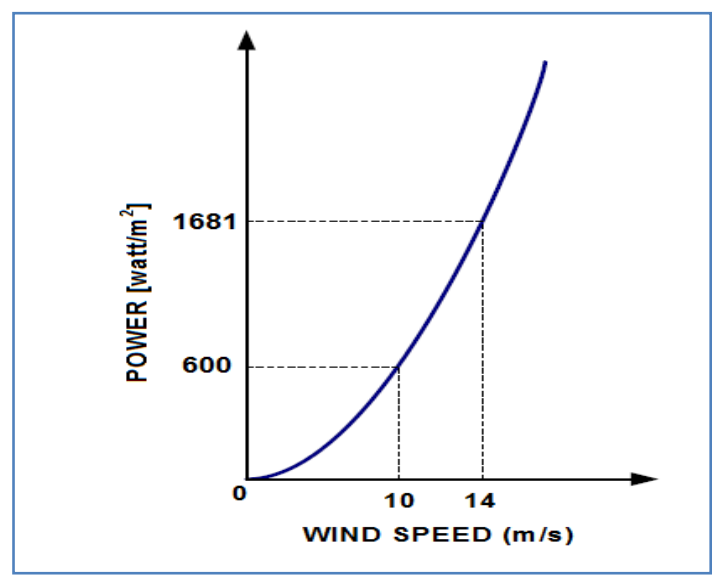

Figure 1. Relation of power with respect to the wind speed modified [1]

Iskenderun and Antakya regions [2]. In this study, Wind Atlas Analysis and Application Program WAsP software package was used in order to obtain wind map for the related regions. Whole wind map of this region was constructed by Sahin et al. (2005) using Wasp package program [3]. Data of hourly wind speeds and wind directions obtained in regions of Antakya, İskenderun, Karataş, Yumurtalık, Dörtyol, Samandağ and Adana, Turkey were used for this work. Also, wind characteristics and energy potential of BelenHatay regions of Turkey was researched by Sahin and Bilgili (2009) and statistical analyses were performed [4].

Bilgili and Sahin (2009) investigated wind energy density in the southern and southern west region of Turkey through using Weibull and Rayleigh probability density functions, and the Wind Atlas Analysis and Application Program (WAsP) [5]. Also, Bilgili and Sahin (2010) investigated wind energy density in the western region of Turkey by using Weibull and Rayleigh probability density functions, and the Wind Atlas Analysis and Application Program (WAsP) [6].

Bilgili et al. (2009) analyzed statistically wind energy potential in the regions of Akhisar, Bababurnu, Belen, Datça, Foça, Gelendost, Gelibolu, Gökçeada and Söke located in south, south-west and west coasts of Turkey [7]. 


\section{CALCULATION of WIND POWER AND EFFICIENCY}

Maximum wind power that is available to be converted into electric power is expressed by the following equation [8];

$P=\frac{1}{2} \rho A V_{i}^{3}$

Theoretical power determined by equation (2) is multiplied by Betz-Limit in order to obtain maximum turbine power [8];

$P_{T H}=\frac{1}{2} \rho A V_{i}^{3} \times 0.59$

By using the wind speed data, $U_{\infty}$, free-stream of the rotor power efficiency $\left(C_{p}\right)$ are calculated with following equation [9].

$c_{p}=\frac{P_{r}}{\frac{1}{2} \rho U_{\infty}^{3} \pi R^{2}}$

Where $\mathrm{P}_{\mathrm{r}}$ designates real power obtained from wind turbine, $\rho$ is the air density, $U_{\infty}$ is the freestream wind speed and $\mathrm{R}$ is the radius of the rotor.

Flow induction factor (a) is determined using the following equation;

$$
4 a(1-a)^{2}-\mathrm{C}_{\mathrm{P}}=0
$$

At wind speed on the rotor, $\mathrm{U}_{\mathrm{D}}$ to be given initially rather than wind speed in front of the rotor (freestream), $U_{\infty}$ and equations 6 and 7 are used to determine flow induction factor.

$a=\frac{X}{X+4}$

Where, $\mathrm{X}$ is determined by,

$$
X=\frac{P_{\text {real }}}{0.98 .0 .97 \cdot \frac{1}{2} \cdot \rho \cdot A \cdot U_{D}^{3}}
$$

Relation of thrust coefficient $\left(\mathrm{C}_{\mathrm{T}}\right)$ with respect to the flow induction factor (a) is expressed as follows [8].

$$
C_{T}=4 a(1-a)
$$

Wind speed before rotor $\left(U_{\infty}\right)$, and far on the wake $\left(\mathrm{U}_{\mathrm{W}}\right)$ are related with equation (9) [10].

$\lambda=\frac{U_{W}}{U_{\infty}}$

Where, wind speed on the rotor $\left(\mathrm{U}_{\mathrm{D}}\right)$ and wind speed far on the wake $\left(\mathrm{U}_{\mathrm{W}}\right)$ are defined as [8],

$U_{D}=U_{\infty}(1-a)$

$U_{W}=U_{\infty}(1-2 a)$

Thrust of wind is given by equation (12) [9].

$T=2 \rho A_{D} U_{\infty}^{2} a(1-a)^{2}$

\section{IDENTIFICATION of WIND DIRECTIONS FOR TURBINES}

With considering the data presented in Table 1, Figure 2 was constructed. This figure demonstrates yearly wind blowing directions for all turbines. Monthly distributions of wind direction for turbines T01, T02, T03, T04 and T05 are presented in Figures 3 and 4. During the procurement of these figures, numbers of hourly wind direction data used in these directions estimations are numbered on these figures.

Data determined in Table 1 refers the processed wind speed, air temperature, power generation and wind direction by eliminating wind speeds below cut-in speed $(4 \mathrm{~m} / \mathrm{s})$ where turbine starts power generation, eliminating zero and negative values of 
power generation and unrecorded wind direction data.

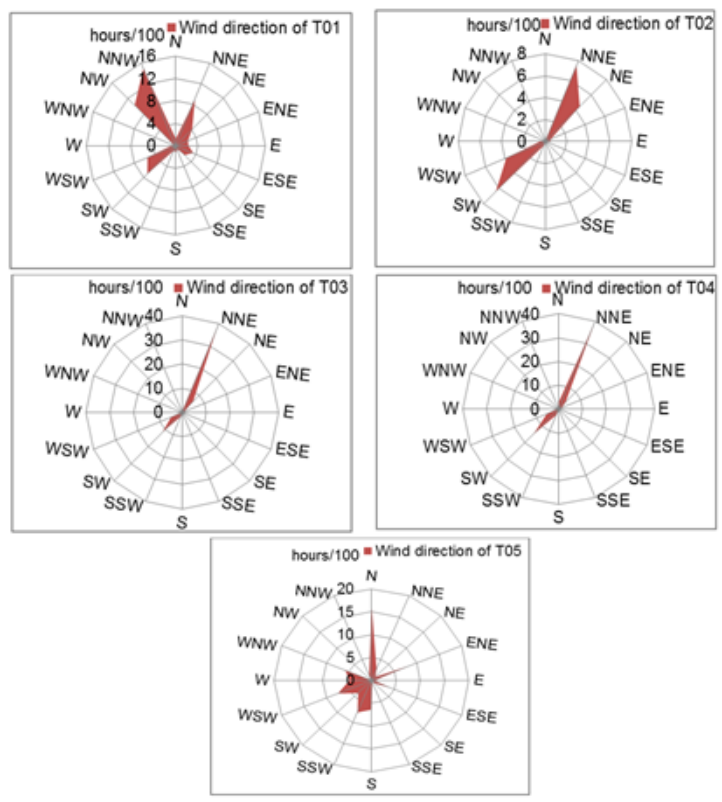

Figure 2. Distributions of wind directions for turbines T01, T02, T03, T04 and T05

Figures 3 and 4 involve average wind directions of T01, T02, T03, T04 and T05 for each month shown with blue numbers. Green patterns inside the figures indicate the amount of data used in determining the monthly wind direction for each discrete turbines. In Figure 3 (Top, right), all hourly wind directions measured for months between June and December were unfortunately unrecorded.

Similarly, these unrecorded wind directions were also designated with bluish color in Table 1.

\section{INTRODUCTION OF CUT-IN AND CUT-OUT SPEEDS}

Average data in Table 1 are acquired with the consideration of cut-in and cut-out speeds, elimination of zero and negative values of power generation, and elimination of unrecorded wind directions (using boundary values). Maximum wind powers were obtained using wind speeds presented in Table 1 and equation 2 was used for calculations. Theoretical wind powers were determined according to the wind speed data given in Table 1 with the utilization of equation 3 . Efficiency calculations were performed by equation 4 . Real powers were directly taken from Table 1 which were computed by taking average values of hourly data.

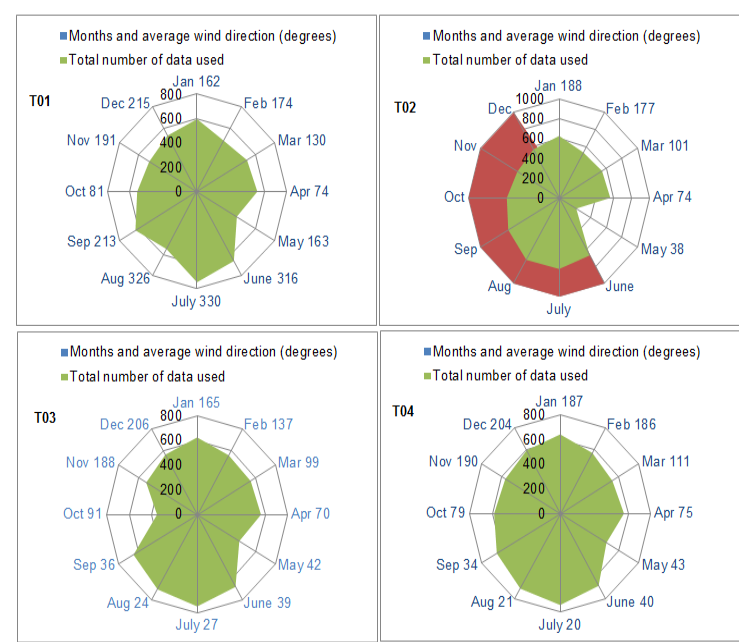

Figure 3. Monthly distributions of wind direction for turbines T01, T02, T03 and T04

= Months and average wind direction (degrees)

$=$ Total number of data used

T05

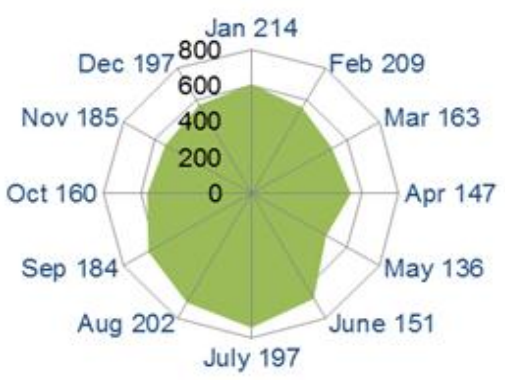

Figure 4. Monthly distributions of wind direction for turbine T05

These estimations were given for each discrete turbines distributed for each months of 2010 year. Table 2 contains related computed data for turbines T01, T02, T03, T04 and T05. 
Table 1. Monthly average wind data (Considering boundary values)

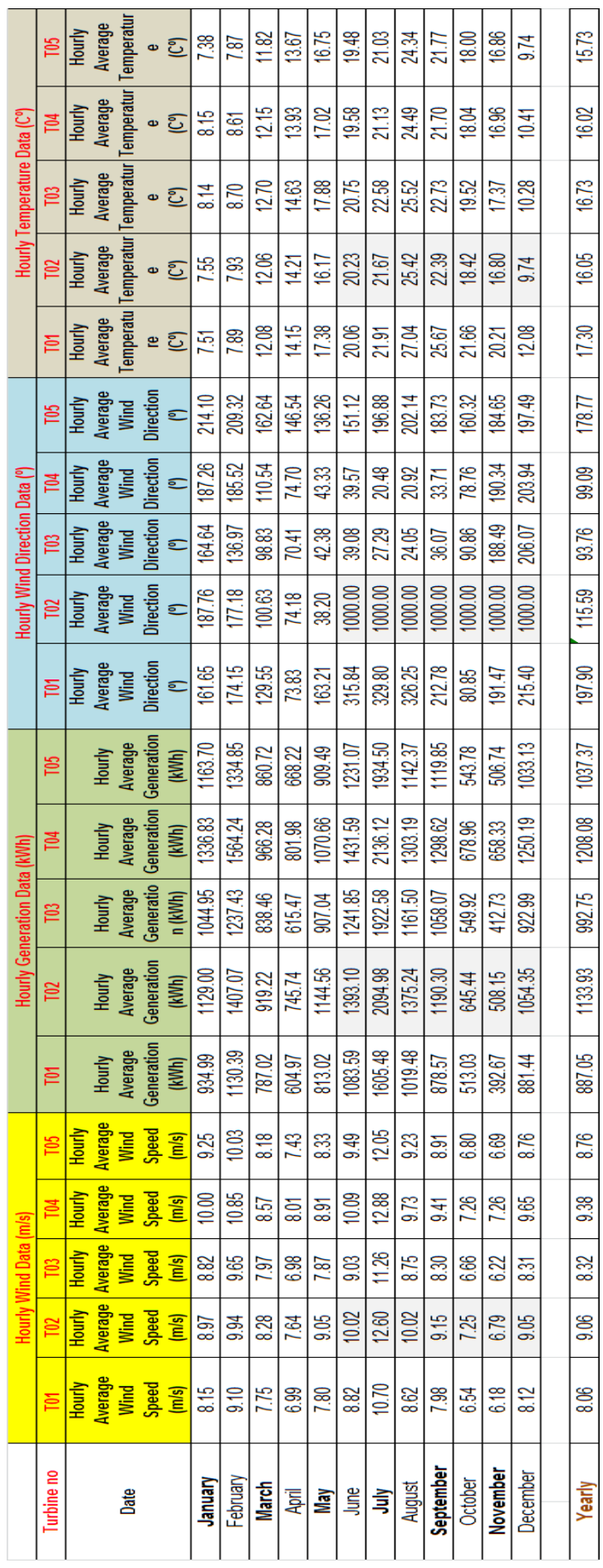

Distribution of $C_{p}-\lambda$ for four turbines regarding equations (4) and (9) is given in Figure 5, whereas, $C_{T}-\lambda$ variation of the same turbines is shown in Figure 6 with using equations (8) and (9).

Figure 7 presents change of power efficiency, $C_{p}$ with respect to the flow induction factor, a by considering equations (7), (6) and finally (5) respectively.

Figure 7 presents change of power efficiency, $C_{p}$ with respect to the flow induction factor, a by considering equations (7), (6) and finally (5) respectively.

As it is mentioned above, thrust coefficient $\left(C_{T}\right)$ and flow induction factor (a) are related by equation 8 . This relation considering four turbines is given in Figure 8.

Wind speed far on the wake, $\left(\mathrm{U}_{\mathrm{W}}\right)$ and wind speed in front of the rotor, $U_{\infty}$ are related through exploitation of equation 11 as demonstrated in Figure 9.

For determination of data presented in Figure 10, equation 10 was used in order to relate wind speed on the rotor $\left(\mathrm{U}_{\mathrm{D}}\right)$ and in front of the rotor, $U_{\infty}$.

By using equation 10, free-stream velocity, $U_{\infty}$ was estimated. Generated real powers were given in table 2. Consequently, variation of real power generation with free-stream velocity, $U_{\infty}$ are presented in Figure 11. When this figure is carefully analyzed, it is observed that through approaching cut-in and cut-out speeds, power generations either stop or approach to a limit. Equation 12 gives the relation between thrust force, $\mathrm{T}$ and free-stream wind speed, $U_{\infty}$ for all turbines considering twelve months and obtained results are shown in Figure 12.

Variations of actual power generation and trust force, $\mathrm{T}$ with free-stream wind speed, $U_{\infty}$ for all turbines throughout twelve months are more or less same. 
Table 2. Power efficiencies of turbines T01, T03, T04, and T05 turbines.

\begin{tabular}{|c|c|c|c|c|c|}
\hline Turbine no & $\begin{array}{c}\text { Wind speed } \\
(\mathrm{m} / \mathrm{s})\end{array}$ & $\begin{array}{c}\text { Maximum } \\
\text { Power } \\
(\mathrm{kW})\end{array}$ & $\begin{array}{c}\text { Theoretical } \\
\text { Power } \\
(\mathrm{kW})\end{array}$ & $\begin{array}{l}\text { Real } \\
\text { Power } \\
(\mathrm{kW}) \\
\end{array}$ & Efficiency \\
\hline \multirow{15}{*}{ 은 } & 4.8542 & 445.6982 & 264.1174 & 115.8390 & 0.2599 \\
\hline & 6.0351 & 856.5000 & 507.5556 & 251.3872 & 0.2935 \\
\hline & 7.1572 & 1428.5968 & 846.5759 & 426.2730 & 0.2984 \\
\hline & 8.2743 & 2207.3699 & 1308.0710 & 661.6781 & 0.2998 \\
\hline & 9.4016 & 3238.0499 & 1918.8444 & 974.3245 & 0.3009 \\
\hline & 10.4749 & 4478.5340 & 2653.9461 & 1329.9973 & 0.2970 \\
\hline & 11.5412 & 5990.0773 & 3549.6754 & 1701.8768 & 0.2841 \\
\hline & 12.4639 & 7544.7621 & 4470.9701 & 2008.2902 & 0.2662 \\
\hline & 13.4355 & 9450.2355 & 5600.1395 & 2285.4070 & 0.2418 \\
\hline & 14.3531 & 11521.6548 & 6827.6473 & 2497.6512 & 0.2168 \\
\hline & 15.2248 & 13751.0976 & 8148.7986 & 2673.9116 & 0.1945 \\
\hline & 16.1984 & 16561.4152 & 9814.1720 & 2724.9523 & 0.1645 \\
\hline & 17.0716 & 19386.5748 & 11488.3406 & 2798.0730 & 0.1443 \\
\hline & 17.8630 & 22209.8284 & 13161.3798 & 2864.3308 & 0.1290 \\
\hline & 18.7791 & 25805.0456 & 15291.8789 & 2884.7340 & 0.1118 \\
\hline \multirow{15}{*}{ م. } & 4.9233 & 464.9877 & 275.5483 & 134.7493 & 0.2898 \\
\hline & 6.0929 & 881.3775 & 522.2978 & 276.0047 & 0.3132 \\
\hline & 7.2370 & 1476.8998 & 875.1999 & 464.1775 & 0.3143 \\
\hline & 8.3490 & 2267.7116 & 1343.8291 & 718.9983 & 0.3171 \\
\hline & 9.4530 & 3291.4989 & 1950.5179 & 1040.5259 & 0.3161 \\
\hline & 10.5174 & 4533.2110 & 2686.3473 & 1398.1634 & 0.3084 \\
\hline & 11.5628 & 6023.8053 & 3569.6624 & 1780.7973 & 0.2956 \\
\hline & 12.5354 & 7675.2377 & 4548.2890 & 2097.2404 & 0.2732 \\
\hline & 13.4731 & 9529.8545 & 5647.3212 & 2359.2805 & 0.2476 \\
\hline & 14.4110 & 11661.7551 & 6910.6697 & 2598.4248 & 0.2228 \\
\hline & 15.3588 & 14117.2667 & 8365.7877 & 2751.5994 & 0.1949 \\
\hline & 16.2030 & 16575.5669 & 9822.5582 & 2815.4732 & 0.1699 \\
\hline & 17.2275 & 19922.5552 & 11805.9586 & 2917.2658 & 0.1464 \\
\hline & 18.1135 & 23157.4471 & 13722.9316 & 2894.9068 & 0.1250 \\
\hline & 19.0480 & 26929.7331 & 15958.3603 & 2930.7750 & 0.1088 \\
\hline \multirow{15}{*}{ S } & 4.8807 & 453.0365 & 268.4661 & 122.4706 & 0.2703 \\
\hline & 6.0234 & 851.5431 & 504.6181 & 248.5066 & 0.2918 \\
\hline & 7.1199 & 1406.3880 & 833.4151 & 405.8159 & 0.2886 \\
\hline & 8.2053 & 2152.6312 & 1275.6333 & 611.2681 & 0.2840 \\
\hline & 9.3222 & 3156.7560 & 1870.6702 & 886.1574 & 0.2807 \\
\hline & 10.3743 & 4350.6705 & 2578.1751 & 1193.7902 & 0.2744 \\
\hline & 11.4162 & 5797.5271 & 3435.5716 & 1521.2887 & 0.2624 \\
\hline & 12.4037 & 7435.9902 & 4406.5127 & 1817.1450 & 0.2444 \\
\hline & 13.3638 & 9299.6407 & 5510.8982 & 2083.4820 & 0.2240 \\
\hline & 14.3495 & 11513.0491 & 6822.5476 & 2348.4563 & 0.2040 \\
\hline & 15.2871 & 13920.4128 & 8249.1335 & 2591.5827 & 0.1862 \\
\hline & 16.2272 & 16650.0439 & 9866.6927 & 2792.9743 & 0.1677 \\
\hline & 17.1461 & 19641.7550 & 11639.5585 & 2925.3417 & 0.1489 \\
\hline & 18.0498 & 22913.7882 & 13578.5411 & 2957.9491 & 0.1291 \\
\hline & 19.0750 & 27044.1911 & 16026.1873 & 2982.0494 & 0.1103 \\
\hline \multirow{18}{*}{ 인 } & 078 & 30282.4839 & 1794 & 2977.9515 & 0.0983 \\
\hline & 20.8706 & 35423.2427 & 20991.5512 & 2983.6730 & 0.0842 \\
\hline & 21.9236 & 41059.6220 & 24331.6278 & 2978.8525 & 0.0725 \\
\hline & 4.8353 & 440.4980 & 261.0359 & 111.9293 & 0.2541 \\
\hline & 6.0091 & 845.4752 & 501.0223 & 235.7734 & 0.2789 \\
\hline & 7.0869 & 1386.9045 & 821.8693 & 384.7237 & 0.2774 \\
\hline & 8.1803 & 2133.0148 & 1264.0088 & 585.6881 & 0.2746 \\
\hline & 9.2691 & 3103.0995 & 1838.8738 & 850.4058 & 0.2741 \\
\hline & 10.3372 & 4304.1979 & 2550.6358 & 1155.1794 & 0.2684 \\
\hline & 11.3677 & 5723.9545 & 3391.9730 & 1470.3233 & 0.2569 \\
\hline & 12.3900 & 7411.3334 & 4391.9013 & 1789.1887 & 0.2414 \\
\hline & 13.3765 & 9326.2484 & 5526.6657 & 2055.6961 & 0.2204 \\
\hline & 14.3002 & 11394.7150 & 6752.4237 & 2293.1810 & 0.2012 \\
\hline & 15.2531 & 13827.9953 & 8194.3676 & 2514.0166 & 0.1818 \\
\hline & 16.1750 & 16489.7061 & 9771.6777 & \begin{tabular}{|l|}
2711.1743 \\
\end{tabular} & 0.1644 \\
\hline & 17.0856 & 19434.4234 & 11516.6953 & 2821.0584 & 0.1452 \\
\hline & 18.0232 & 22812.7127 & 13518.6446 & 2901.7680 & 0.1272 \\
\hline & 19.1645 & 27426.6182 & 16252.8108 & 2971.9598 & 0.1084 \\
\hline
\end{tabular}

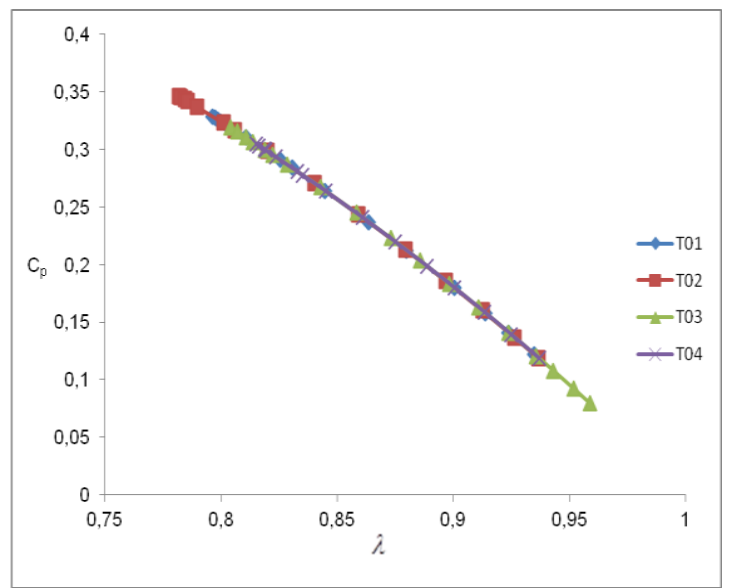

Figure 5. $\mathrm{C}_{\mathrm{p}}-\lambda$ distribution

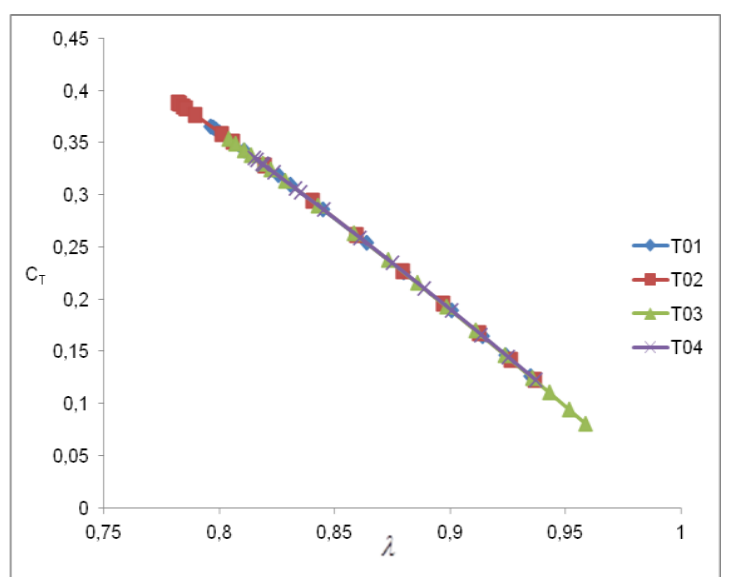

Figure 6. $\mathrm{C}_{\mathrm{T}}-\lambda$ distribution

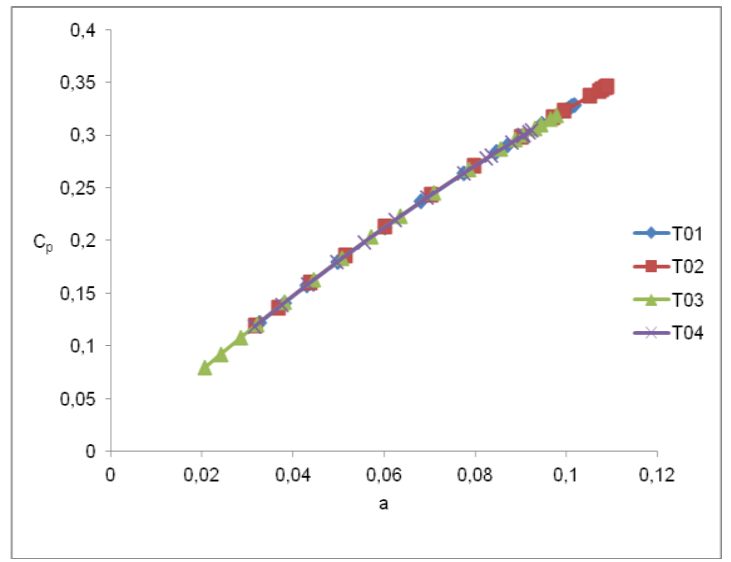

Figure 7. $\mathrm{C}_{\mathrm{p}}$-a distribution 


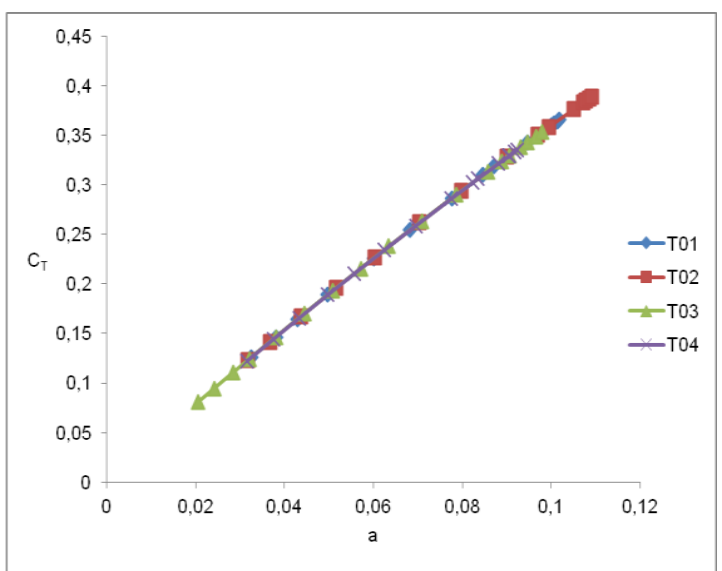

Figure 8. $\mathrm{C}_{\mathrm{T}}$-a distribution

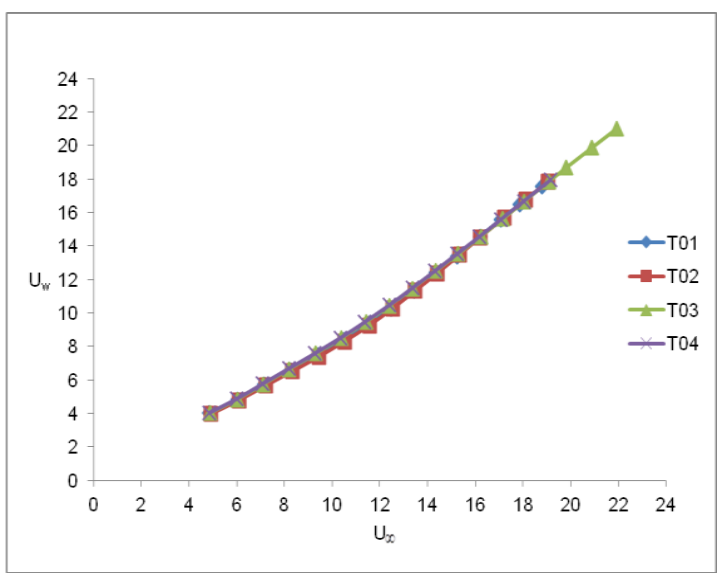

Figure 9. $\mathrm{U}_{\mathrm{w}}-U_{\infty}$ distribution

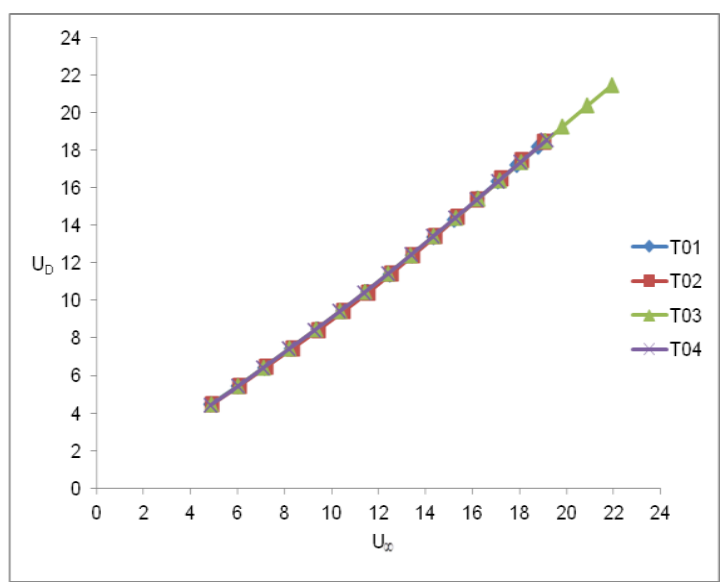

Figure 10. $\mathrm{U}_{\mathrm{D}^{-}} U_{\infty}$ distribution

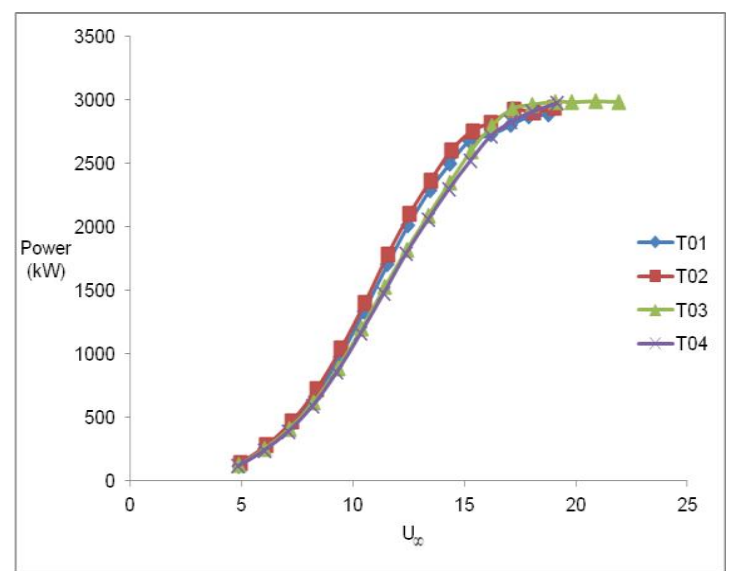

Figure 11. Power- $U_{\infty}$ distribution

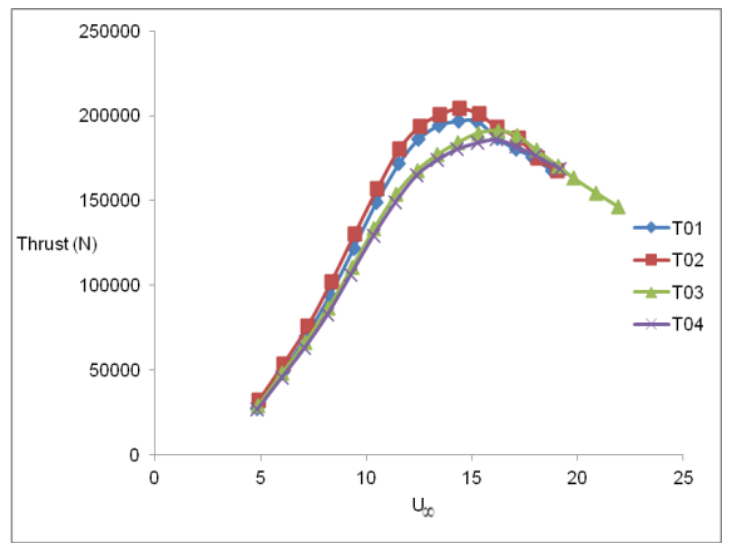

Figure 12. Thrust- $U_{\infty}$ distribution

Figure 13 refers to total energy generation of five turbines with an average wind speed throughout twelve months. It can be seen that all turbines generates electricity throughout twelve months. The highest power generation occurs in July.

\section{CONCLUSIONS}

According to the data obtained from wind farm, firstly analyses were performed without taking cutin and cut-out speeds into consideration. Monthly averages wind data were used in estimations of related parameters. At very low speeds, turbine cannot generate electricity where it is expressed in its specifications as cut-in speed. Maximum power and real power generally increase with 
increasing free-stream wind speeds $\left(U_{\infty}\right)$ when cut-in speeds are considered, however efficiencies decreases to a meaningful values.

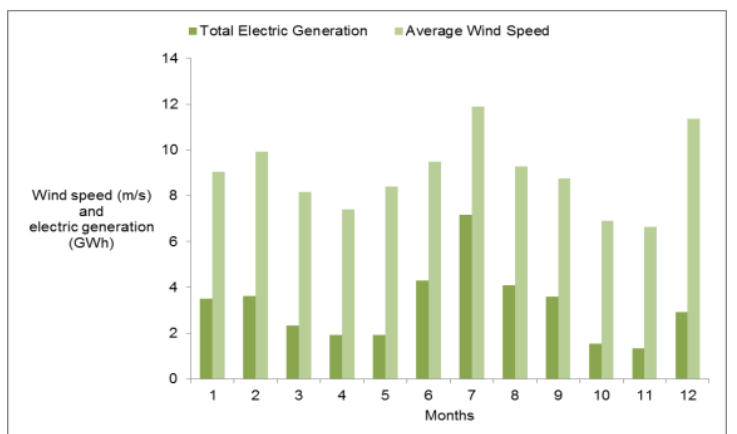

Figure 13. Monthly total electric generations and average wind speeds

It is observed that maximum power generations occur in July for all turbines, when average wind speed $\left(U_{\infty}\right)$ is maximum and air temperature is also high compared with other months for all turbines. In addition, non-stop generations take place in this month for all turbines. The total electric generation of five turbines was $38.09 \mathrm{GWh}$ in the year of 2010. Turbine T04 generated 9.03 GWh electricity. The maximum power was generated by turbine T04, on the other hand, turbine T01 generated $6.12 \mathrm{GWh}$ electricity. Although both turbines are installed in the same wind farm, the difference of electric production in between turbine T01 and T04 is 33\% in the year of 2010. This wind farm is situated in the valley containing many hills, crests and roughness. This topographic condition of the farm effects wind directions and magnitude of wind speed, $U_{\infty}$.

\section{REFERENCES}

1. Tanrı̈̈ven, M., 2011. Rüzgâr ve Güneş Enerjili Güç Sistemleri, (http://www.yildiz.edu.tr/ $\sim$ tanriov/RG1.pdf).

2. Bilgili, M., Şahin, B., Kahraman, A., 2004. Wind Energy Potential in Antakya and İskenderun regions, Turkey, Journal of Renewable Energy, 29(2004), 1733-1745.

3. Şahin, B., Bilgili, M., Akıllı, H., 2005. The wind power potential of the eastern
Mediterranean region of Turkey, Journal of Wind Engineering and Industrial Aerodynamics, 93(2005), 171-183.

4. Şahin, B., Bilgili, M., 2009. Wind Characteristics and Energy Potential in BelenHatay, Turkey, International Journal of Green Energy, 6:2, 157-172.

5. Bilgili, M. and Şahin, B., 2009. Investigation of Wind Energy Density in the Southern and Southwestern Region of Turkey, Journal of Energy Engineering, 135:1(12),12-20.

6. Bilgili, M., Şahin, B., 2010. Statistical Analysis of Wind Energy Density in the Western Region of Turkey, Energy Sources, Part A: Recovery, Utilization, and Environmental Effects, 32:13, 1224-1235.

7. Bilgili, M., Şahin, B., Şimşek, E., 2009. Türkiye'nin Güney, Güneybatı ve Batı Bölgelerindeki Rüzgar Enerjisi Potansiyeli, Journal of Thermal Science and Technology, 30(1),1-12.

8. Burton, T., Jenkins, N., Sharpe, D., Bossanyi, E., 2011. Wind Energy Handbook, John Wiley \& Sons, Ltd., United Kingdom.

9. Manwell, J., F., Mcgowan, J., G., Rogers, A., L., 2009. Wind Energy Explained Theory, Design and Application. John Wiley \& Sons, Ltd., United Kingdom.

10. Milli Eğitim Bakanlığı, 2012. Yenilenebilir Enerji Teknolojileri, Rüzgâr Türbinlerinde Üretilen Alternatif Akımın Temelleri, (http://www.megep.meb.gov.tr/mte_program_ modul/moduller_pdf/Rüzgar Türbinlerinde Üretilen Alternatif Akımın Temelleri.pdf),

11. Ağçay, M., 2007. Türkiye'nin Elektrik Enerjisi Arz Talep Dengesinin Tespiti, Üretim Projeksiyonuna Yönelik Rüzgar Elektrik Santrali Tasarımı RES'in Kurulum Maliyetlerinin ve Üretim Parametrelerinin Analizinin Matlab\&Simulink ile Yazılan Programda Yapılması, Bitirme Tezi-EMO Proje Yarışması, Yıldız Teknik Üniversitesi, Elektrik Elektronik Fakültesi, Elektrik Mühendisliği Bölümü, İstanbul.

12. İlhan, A., 2014. Efficiency Analysis of an Installed Wind Farm, MSc Thesis, Çukurova University, Institute of Natural and Applied Sciences, Adana. 